\title{
Hubungan antara Kecemasan dan Motivasi dengan Prestasi Atlet Bola Voli di Masa Pandemi Covid-19
}

\section{The Relationship between Anxiety and Motivation and Achievement of Volleyball Athletes during the Covid-19 Pandemic}

\author{
Aep Rohendi ${ }^{1}$, Ali Budiman ${ }^{2}$, Mohamad Gelar Cipta ${ }^{3}$ \\ ${ }^{1,2,3}$ Program studi PJKR, STKIP Pasundan, Jalan Permana No. 32B Kota Cimahi, Jawa Barat, \\ 40512, Indonesia
}

\begin{abstract}
Abstrak
Penelitian ini bertujuan untuk mengetahui apakah kecemasan dan motivasi memiliki hubungan dengan prestasi atlet bola voli PBV Pasundan di masa pandemi covid-19 Metode dalam penelitian ini menggunakan metode deskriptif dengan korelasional, populasi dalam penelitian ini atlet PBV Pasundan yang berusia 19 tahun berjumlah 12 atlet, teknik sampling meggunakan purposive sampling, adapun sampel dalam penelitian ini ialah 12 orang. Instrument menggunakan angket kuisioner dengan skala likert, teknik analisis data menggunakan analisis data statistika dengan berbantuan aplikasi spss versi 24. Hasil penelitian menunjukan bahwa (1)Terdapat hubungan yang signifikan antara kecemasan dengan prestasi atlet, dengan kata lain semakin bisa ditanggulangi serta diminimalisir kecemasan setiap atlet maka akan memiliki kecenderungan dapat meningkatkan prestasi atlet itu sendiri terhadap tim. (2) Terdapat hubungan yang signifikan antara motivasi dengan prestasi atlet, dengan kata lain semakin tinggi motivasi atlet untuk berprestasi maka memiliki kecenderungan dapat meningkatkan prestasi atlet itu sendiri terhadap tim. (3) Terdapat hubungan yang signifikan antara kecemasan dan motivasi dengan prestasi atlet PBV Pasundan. Dalam penelitian ini dapat diambil kesimpulan seorang pelatih harus memperhatikan aspek psikologis atletnya seperti tingkat kecemasan dan motivasi karena sangatlah berpengaruh terhadap penampilan atlet di lapangan.
\end{abstract}

Kata kunci: kecemasan, motivasi, prestasi, bola voli

\begin{abstract}
This study aims to determine whether anxiety and motivation have a relationship with the achievement of PBV Pasundan volleyball athletes during the Covid-19 pandemic. The method in this study uses descriptive methods with correlational, the population in this study was 12 athletes of PBV Pasundan aged 19 years. sampling using purposive sampling, while the sample in this study was 12 people. The instrument uses a questionnaire questionnaire with a Likert scale, the data analysis technique uses statistical data analysis with the help of the SPSS version 24 application.The results show that (1) there is a significant relationship between anxiety and athlete's performance, in other words, the more it can be handled and minimized the anxiety of each athlete. it will have a tendency to increase the athlete's own performance against the team. (2) There is a significant relationship between motivation and athlete achievement, in other words, the higher the athlete's motivation to achieve, the tendency to increase the athlete's own performance against the team. (3) There is a significant relationship between anxiety and motivation with the achievement of PBV Pasundan athletes. In this study, it can be concluded that a coach must pay attention to the psychological aspects of his athletes such as the level of anxiety and motivation because they greatly affect the athlete's appearance on the field.
\end{abstract}

Keywords: anxiety, motivation, achievement, volley ball. 



\section{PENDAHULUAN}

Olahraga adalah sarana bagi manusia untuk mempertahankan kesehatan dan kebugaran tubuh serta dengan olahraga dapat membentuk manusia yang sehat jasmani, rohani yang mempunyai kepribadian disiplin, oleh karena itu olahraga ini dijadikan sebagai sarana untuk menjaga kesehatan maka, olahraga secara terus-menerus selalu di upayakan keberadaannya (Hendri, 2020). Sedangkan latihan merupakan aktivitas olahraga/jasmani yang sistematik, dilakukan dalam waktu lama, ditingkatkan secara progresif dan individual yang mengarah kepada ciri-ciri fungsi psikologis dan fisiologis manusia untuk mencapai sasaran yang ditentukan (Bompa \& Buzzichelli, 2018).

Dalam perkembangannya olahraga bola voli merupakan olahraga yang cukup populer di Indonesia ini terbukti dengan banyaknya di selenggarakannya eventevent atau kompetisi olahraga bola voli baik di tingkat daerah Pekan olahraga daerah (PORDA) maupun ditingkat nasional seperti Pekan Olahraga Nasional (PON). PON merupakan pesta olahraga nasional di Indonesia yang diadakan setiap empat tahun sekali dan diikuti seluruh provinsi di Indonesia (Jamalong, 2014).

Pada awal tahun 2020, dunia sedang waspada dengan sebuah virus yang disebut dengan corona virus (COVID-19). Penularan COVID-19 sangatlah cepat sehingga Organisasi Kesehatan Dunia (WHO) menetapkan status pandemi ini menandakan penyebaran COVID-19 berlangsung sangatlah cepat hingga hampir tak ada negara di dunia yang dapat terhindar dari virus corona (Karyono et al., 2020). COVID-19 telah menjadi pandemi, sehingga pemerintah di bebagai negara telah menerapkan lockdown atau karantina. Pengertian karantina menurut UU Republik Indonesia Nomor 6 tahun 2018 tentang Kekarantinaan Kesehatan adalah pembatasan kegiatan dan/atau pemisahan seseorang yang terpapar penyakit menular sebagaimana ditetapkan dalam peraturan perundang-undangan meskipun belum menunjukkan gejala apapun untuk mencegah kemungkinan penyebaran ke orang di sekitarnya (UU No 6 tahun 2018). Pemerintah Indonesia telah menghimbau warga untuk tetap di dalam rumah dan mengisolasi diri. Salah satunya Pemerintah Indonesia menerapkan aturan PSBB yang merupakan singkatan dari Pembatasan Sosial Berskala Besar yang dibuat dalam rangka Penanganan COVID-19. Hal ini dilakukan dengan harapan virus tidak menyebar lebih luas dan upaya penyembuhan dapat berjalan maksimal (Hammami et al., 2020).

Sebagai dampak dari PSBB, semua kegiatan olahraga dibatasi, dengan mewajibkan para atlet untuk berlatih secara mandiri di tempat masing-masing. Ak:ibatnya secara psikologi para atlet mengalami juga gejala-gejala kecemasan dan menurunnya 
motivasi berlatih, hal ini terungkap dari hasil wawancara penulis dengan atlet binaan di PBV Pasundan, (Bulan Juli, Tahun 2020). Kecemasan yang mereka alami terkait dengan tidak menentunya masa kompetisi, sedangkan tingkat motivasinya pun cenderung menurun, karena berlatih tanpa didampingi pelatih. Pada seorang atlet kecemasan dapat menjadi masalah yang serius terhadap performa permainan dilapangan dalam sebuah pertandingan. Terkadang seorang atlet akan merasa cemas ketika saat bertanding melawan tim-tim besar yang memiliki kemampuan yang hampir sama bahkan bisa melebihi kemampuan tim yang dia perjuangkan. Setiap atlet tentu saja selalu berhadapan dengan pertandingan yang menimbulkan suatu kondisi kompetisi, dan dalam setiap kompetisi atau pertandingan tersebut kecemasan selalu hadir dalam diri atlet. Karena memang pada dasamya setiap atlet ingin mencapai hasil yang terbaik berdasarkan kemampuan-kemampuan yang diamiliki dalam mencapai prestasi (Festiawan, 2015).

\section{METODE}

Metode yang digunakan dalam penelitian ini adalah metode deskriptif kuantitatif dengan pendekatan korelasional. Metode tersebut digunakan untuk mencari keterkaitan atau hubungan dari satu variabel dengan variabel lainnya. Model korelasi multiple digunakan jika variabel-variabel bebas dari penelitiannya secara teoretik diyakini independen atau tidak ada variabel intervening diantara variabel-variabel bebasnya (Sugiyono, 2017).

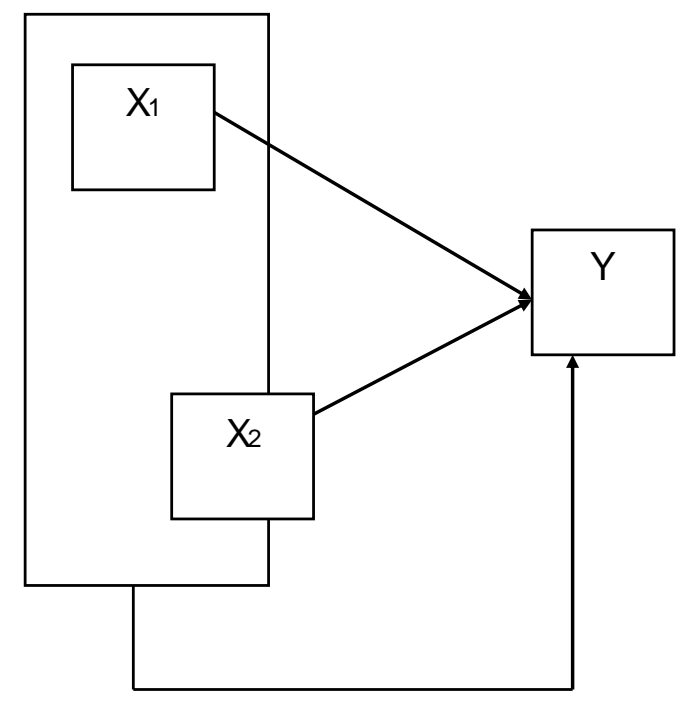

\section{Gambar 1. Korelasi Antara X1 dan X2 Dengan Y}

Keterangan :

$\mathrm{X}_{1}$ : Kecemasan 
$\mathrm{X}_{2}$ : Motivasi Berprestasi

$\mathrm{Y}:$ Prestasi Atlet

\section{HASIL DAN PEMBAHASAN}

\section{Hasil}

Deskripsi data keterampilan Kecemasan (Xi)

Hasil penelitian dari seluruh responden instrumen kecemasan yang berjumlah 12 atlet, diperoleh rata-rata sebesar 85 simpangan baku sebesar 5,29 modus sebesar 91, median sebesar 85 nilai tertinggi sebesar 93 dan nilai terendah 77, selanjutnya data kecemasan disajikan dalam bentuk distribusi frenkuensi seperti pada tabel dibawah ini:

Tabel 1. Distribusi Frekuensi Kecemasan (X)

\begin{tabular}{cccc}
\hline$N_{0}$ & Rentang skor & Frekuensi & Presentasi \\
1 & $85-112$ & 6 & $50 \%$ \\
2 & $57-84$ & 6 & $50 \%$ \\
3 & $29-56$ & 0 & $0 \%$ \\
4 & $0-28$ & 0 & $0 \%$ \\
& Jumlah & 12 & $100 \%$ \\
\hline
\end{tabular}

Dari tebel dapat diketahui bahwa data diperoleh dari 12 orang sampel dapat di klafikasikan dalam beberapa kelompok di antaranya, 6 orang berada pada skor rentang 85-112 dengan presentase sebesar 50\%, 6 orang berada pada skor rentang 5784 dengan presentase sebesar 50\%, 0 orang berada pada skor rentang 29-56 dengan presentase sebesar $0 \%$, dan 0 orang berada pada skor rentang 0-28 dengan presentase sebesar $0 \%$.

Deskripsi Data Motivasi (X)

Hasil penilitian dari selruh responden instrumen motivasi yang berjumlah 12 atlet, diperoleh rata-rata hasil angket kuisioner motivasi sebesar 156,41 simpangan baku sebesar 10,09, modus sebesar 162 median sebesar 158 nilai tertinggi sebesar 171 dan nilai terendah sebesar 136. selanjutnya data motivasi disajikan dalam bentuk distribusi frekuensi seperti pada table 2. 
Tabel 2. Distribusi Frekuensi Kecemasan $(\mathbf{X})$

\begin{tabular}{lrcc}
\hline No & Rentang skor & Frekuensi & Presentase \\
\hline 1 & $85-112$ & 6 & $50 \%$ \\
2 & $57-84$ & 6 & $50 \%$ \\
3 & $29-56$ & 0 & $0 \%$ \\
4 & $0-28$ & 0 & $0 \%$ \\
& Jumlah & 12 & $100 \%$ \\
\hline
\end{tabular}

\section{Deskripsi Data Prestasi Atlet (Y)}

Hasil observasi peneliti rneskipun rnenjalani latihan rnandiri dan sesekali rnelaksanakan latihan bersarna, rnendapatkan hasil bahwa prestasi tirn bola voli PBV Pasundan rnendapatkan juara pertarna dalarn kejuaraan IVOBA yang di selenggarakan di Kota Bandung Tahun 2020. Berdasarkan uji signifikasi koefisien ting $=2,89$. $\mathrm{t} \%$ set $=1,78$ sehingga dapat disimpulkan bahwa koefesien korelasi antara motivasi (X2) dengan prestasi atlet (Y) sebesar 0.781 adalah sangat signifikan ini berarti bahwa terdapat hubungan positif antara motivasi (X) dengan prestasi atlet (Y). hasil kofosien determinasi adalah $\mathrm{r} x y 2=(0.781)$ atau $78,1 \%$. Ini berarti bahwa 78, $1 \%$ motivasi memiliki hubungan dengan prestasi atlet PBV Pasundan.

\section{Pembahasan}

Gejala kecemasan pada atlet PBV pasundan dapat ditanggulangi dengan sosok pelatih yang bisa terus memberikan motivasi agar kecemasan mereka berubah menjadi sebuah semangat dan pembuktiaan sehingga dalam setiap kompetisi terlihat setiap atlet dengan sungguh-sungguh melaksakan setiap arahan dan motivasi yang diberikan oleh pelatih. Rasa kecemasan yang dapat ditanggulangi menimbulkan motivasi yang tinggi untuk berprestasi, oleh kama itu dalam setiap bencana ataupun dalam kondisi yang lainnya peran pelatih sangat vital untuk bisa menanggulangi sisi aspek mental para atlet agar bisa memberikan yang terbaik dalam setiap kompetisi. Hasil penelitian ini memperkuat teori yang menyatakan bahwa kecemasan berpengaruh besar terhadap penampilan atlet yang dengan sendirinya akan berpengaruh terhadap prestasinya (Prior \& Coates, 2019). Hal ini menunjukkan bahwa tingkat kecemasan pada atlet harus dilatih agar rasa cemas semakin rendah. Selanjutnya diharapkan rasa cemas akan hilang sama sekali, sehingga penampilan atlet dalam mencapai pretasinya dapat optimal. Hal ini sejalan dengan hasil penelitian yang mendapati sebuah kesimpulan bahwa adanya hubungan kecemasan dengan performa pada atlet bola voli pada event kejuaraan antar 
Desa Kabupaten Cirebon (Erdiyanti \& Maulana, 2019), hal ini memperkuat penjelasan menurut Ada beberapa aspek psikologis yang dapat mempengauhi performa seorang atlet dalam menghadapi pertandingan, antara lain keyakinan diri (selfefficacy), motivasi berprestasi, stres, kecemasan, emosi, dan goal setting. Tiga pilar prestasi atlet adalah fisik, tekhnik, dan mental (Hardi \& Nurama, 2019). Di Indonesia faktor psikologis adalah pilar utama prestasi. Dengan mental yang unggul, seorang atlet dapat mengolah kemampuan fisik dan tekhniknya dalam bertanding untuk berprestasi. Namun fisik yang prima juga merupakan salah satu aset penting yang hams dipertahankan oleh seorang atlet. Faktor psikologis lain yang dapat membantu atau menunjang prestasi atlet adalah motivasi. Motivasi merupakan suatu dorongan atau suatu kehendak yang mendasari munculnya suatu tingkah laku. Jadi motivasi dapat diartikan sebagai suatu kebutuhan atau pendorong untuk melakukan sesuatu hal atau menampilkan perilaku tertentu. Peranan motivasi terhadap prestasi olahraga terutama olahraga kompetitif sangat penting. Hasil penelitian ini didukung oleh Robert N. Singer yang mengemukakan bahwa "prestasi olahraga itu sama dengan keterampilan yang diperoleh melalui motivasi yang menyebabkan atlet yang bertahan dalam latihan, ditambah dengan motivasi yang menyebabkan atlet berlatih keras" (Ginanjar, 2018; Priyanto, 2013).

Berdasarkan hasil pengujian hipotesis, temyata ketiga hipotesis yang diajukan secara signifikan dapat diterima. Uraian masing-masing penerimaan ketiga hipotesis yang dimakasud dapat dijelaskan sebagai berikut. Hasil data yang pertama kecemasan memiliki hubungan dengan prestasi atlet hal itu terbukti dengan analisis data yang telah disajikan, berdasarkan observasi setiap atlet PBV Pasundan memiliki kecemasan takut akan tidak mendapatkan hasil terbaik, pada variabel motivasi memiliki hubungan dengan prestasi atlet. Hal ini terjadi karena motivasi mereka berada pada kategori tinggi sesuai dengan analisis data yang telah dipaparkan sebelumnya, serta berdasarkan hasil observasi seluruh atlet PBV Pasundan sangat termotivasi untuk bisa meraih prestasi terbaik, hal ini terbuktidengan PBV Pasundan menjadi juara 1 pada gelaran IVOBA yang diselenggarakan di Kota Bandung Tahun 2020.

\section{KESIMPULAN}

Dari hasil pengujian hipotesis yang diajukan terbukti bahwa variabel kecemasan dan motivasi dengan prestasi atlet PBV Pasundan baik secara parsial maupun secara bersama-sama mempengaruhi prestasi atlet PBV Pasundan. Oleh karena itu, hasil analisis dan pengujian hipotesis dapat disimpulkan bahwa: Terdapat hubungan yang signifikan 
antara kecemasan dengan prestasi atlet. Dengan kata lain kecemasan atlet yang rendah mampu meningkatkan prestasi atlet tersebut. Terdapat hubungan yang signifikan antara motivasi dengan prestasi atlet. Dengan kata lain semakin tinggi motivasi atlet untuk berprestasi maka dapat meningkatkan prestasi atlet. Terdapat hubungan yang signifikan antara kecemasan dan motivasi dengan prestasi atlet bolavoli PBV Pasundan.

\section{DAFTAR PUSTAKA}

Bompa, T. O., \& Buzzichelli, C. (2018). Periodization-: theory and methodology of training. Human kinetics.

Erdiyanti, Y. P., \& Maulana, A. (2019). Hubungan Kecemasan dengan Performa Atlet Bola Voli pada Event Kejuaraan Antar Desa Di Desa Orimalang Kec. Jamblang Kab. Cirebon. Prophetic: Professional, Empathy and Islamic Counseling Journal, 2(2), 269. https://doi.org/10.24235/prophetic.v2i2.5813

Festiawan, R. (2015). Pedagogi Olahraga (Sport Pedagogy). Universitas Jenderal Soedirman, 1-23.

Ginanjar, A. (2018). The Tactical Games Modelsand Motivation Learningof Physical Fitness The Vocational School Students. Jurnal Kependidikan Penelitian Dan Inovasi Pembelajaran, 2(2), 409-419. https://doi.org/https://doi.org/10.21831/jk.v2i2.10746

Hammami, A., Harrabi, B., Mohr, M., \& Krustrup, P. (2020). Physical activity and coronavirus disease 2019 (COVID-19): specific recommendations for home-based physical training. Managing Sport and Leisure, $O(0)$, 1-6. https://doi.org/10.1080/23750472.2020.1757494

Hardi, V. J., \& Nurama, D. (2019). Hubungan Tingkat Konsentrasi terhadap Ketepatan Memanah. 5(1).

Hendri, G. (2020). Motivasi Siswa Dalam Proses Pembelajaran Pendidikan Jasmani Olahraga Kesehatan Di SMAN 1 Padang Sago Padang Pariaman. Jurnal Patriot, 2, 171-181. http://patriot.ppj.unp.ac.id/index.php/patriot/article/view/533

Jamalong, A. (2014). Peningkatan Prestasi Olahraga Nasional Secara Dini Melalui Pusat Pembinaan Dan Latihan Pelajar (PPLP) Dan Pusat Pembinaan Dan Latihan Mahasiswa (PPLM). Jurnal Pendidikan Olahraga, 3(2), 156-168. http://journal.ikippgriptk.ac.id/index.php/olahraga/article/view/127

Karyono, K., Rohadin, R., \& Indriyani, D. (2020). Penanganan Dan Pencegahan Pandemi 
Wabah Virus Corona (Covid-19) Kabupaten Indramayu. Jurnal Kolaborasi Resolusi Konflik, 2(2), 164. https://doi.org/10.24198/jkrk.v2i2.29127

Prior, E. E., \& Coates, J. K. (2019). Archers' experiences of target panic: an interpretative phenomenological analysis. Qualitative Research in Sport, Exercise and Health, OO(00), 1-18. https://doi.org/10.1080/2159676X.2019.1599061

Priyanto, A. (2013). Peningkatan Motivasi Belajar Gerak Dasar Lari melalui Pendekatan Bermain dalam Pembelajaran Penjas Siswa Kelas V SD I Donotirto Kretek Bantul. Jurnal Pendidikan Jasmani Indonesia, 9(1).

Sugiyono. (2017). Metode penelitian, Pendekatan Kualitatif, Kuantitaif dan $R \& D$ (Alfabeta (ed.); Alfabeta). Alpabeta. https://doi.org/10.1038/132817a0 